\title{
Correction: Intragastric exposure to titanium dioxide nanoparticles induced nephrotoxicity in mice, assessed by physiological and gene expression modifications
}

\author{
Suxin Gui ${ }^{1+}$, Xuezi Sang ${ }^{1 \dagger}$, Lei Zheng ${ }^{1}$, Yuguan Ze ${ }^{1+}$, Xiaoyang Zhao ${ }^{1 \dagger}$, Lei Sheng ${ }^{1}$, Qingqing Sun ${ }^{1}$, Zhe Cheng ${ }^{1}$, \\ Jie Cheng ${ }^{1}$, Renping Hu', Ling Wang ${ }^{1}$, Fashui Hong ${ }^{1 *}$ and Meng Tang ${ }^{2,3^{*}}$
}

\section{Correction}

After publication of this article [1], the authors became aware of the fact that the original version of this article missed equal contributor and corresponding author information.

\begin{abstract}
Author details
${ }^{1}$ Medical College of Soochow University, Suzhou 215123, China. ${ }^{2}$ Key Laboratory of Environmental Medicine and Engineering, Ministry of Education, School of Public Health, Southeast University, Nanjing 210009, China. ${ }^{3}$ Jiangsu key Laboratory for Biomaterials and Devices, Southeast University, Nanjing 210009, China.
\end{abstract}

Received: 11 September 2013 Accepted: 11 September 2013

Published: 9 October 2013

\section{Reference}

1. Gui S, Sang X, Zheng L, Ze Y, Zhao X, Sheng L, Sun Q, Cheng Z, Cheng J, Hu R, Wang L, Hong F, Tang M: Intragastric exposure to titanium dioxide nanoparticles induced nephrotoxicity in mice, assessed by physiological and gene expression modifications. Particle Fibre Toxicol 2013, 10:4.

\section{doi:10.1186/1743-8977-10-51}

Cite this article as: Gui et al: Correction: Intragastric exposure to

titanium dioxide nanoparticles induced nephrotoxicity in mice, assessed by physiological and gene expression modifications. Particle and Fibre Toxicology 2013 10:51.

\footnotetext{
* Correspondence: hongfsh_cn@sina.com; tm@seu.edu.cn

${ }^{\dagger}$ Equal contributors

'Medical College of Soochow University, Suzhou 215123, China

${ }^{2}$ Key Laboratory of Environmental Medicine and Engineering, Ministry of Education, School of Public Health, Southeast University, Nanjing 210009,

China

Full list of author information is available at the end of the article
}

\section{Submit your next manuscript to BioMed Central and take full advantage of:}

- Convenient online submission

- Thorough peer review

- No space constraints or color figure charges

- Immediate publication on acceptance

- Inclusion in PubMed, CAS, Scopus and Google Scholar

- Research which is freely available for redistribution

Submit your manuscript at

www.biomedcentral.com/submit

() Biomed Central
() Biomed Central

(c) 2013 Gui et al.; licensee BioMed Central Ltd. This is an Open Access article distributed under the terms of the Creative Commons Attribution License (http://creativecommons.org/licenses/by/2.0), which permits unrestricted use, distribution, and reproduction in any medium, provided the original work is properly cited. The Creative Commons Public Domain Dedication waiver (http://creativecommons.org/publicdomain/zero/1.0/) applies to the data made available in this article, unless otherwise stated. 